Abstracta Iranica Abstracta Iranica

Revue bibliographique pour le domaine irano-aryen

Volume 29 | 2008

Comptes rendus des publications de 2006

\title{
Diplomacy and murder in Tehran. Alexander Griboyedov and Imperial Russia's mission to the Shah of Persia. London - New York, I. B. Tauris, 2006, 316 p.
}

\section{Florence Hellot}

\section{(2) OpenEdition}

1 Journals

\section{Édition électronique}

URL : http://journals.openedition.org/abstractairanica/28492

DOI : 10.4000/abstractairanica.28492

ISSN : 1961-960X

Éditeur :

CNRS (UMR 7528 Mondes iraniens et indiens), Éditions de l'IFRI

\section{Édition imprimée}

Date de publication : 15 mai 2008

ISSN : 0240-8910

\section{Référence électronique}

Florence Hellot, «Diplomacy and murder in Tehran. Alexander Griboyedov and Imperial Russia's mission to the Shah of Persia. London - New York, I. B. Tauris, 2006, 316 p. », Abstracta Iranica [En ligne], Volume 29 | 2008, document 191, mis en ligne le 14 mars 2016, consulté le 26 septembre 2020. URL : http:// journals.openedition.org/abstractairanica/28492 ; DOI : https://doi.org/10.4000/abstractairanica. 28492

Ce document a été généré automatiquement le 26 septembre 2020.

Tous droits réservés 


\title{
Diplomacy and murder in Tehran. Alexander Griboyedov and Imperial Russia's mission to the Shah of Persia. London - New York, I. B. Tauris, 2006, 316 p.
}

\author{
Florence Hellot
}

Cette nouvelle édition d'un livre déjà publié en 2002, par I. B. Tauris \& Co Ltd reprend le même texte, les mêmes illustrations (parfois présentées avec un décalage d'une page d'une édition à l'autre), la même bibliographie. Une note a été ajoutée dans l'introduction de l'édition de 2006 ; elle se rapporte à un extrait du texte d'Alexandre Pouchkine: A journey to Erzeroum. Le texte de Pouchkine est commenté à l'aide d'un texte de E.N.Grigoriev qui décrit lui aussi le transport du cercueil d'Alexandre Sergeyevitch Griboyedov, auquel il accorde un caractère plus solennel. L'édition de 2006 comporte aussi, sur deux pages qui se trouvent en tête du livre, certains des commentaires qui ont accompagné la sortie du livre en 2002.

\section{INDEX}

Thèmes : 4.2.1. Safavides et Qâjârs 
AUTEURS

FLORENCE HELLOT

Mondes iranien et indien - Paris 